\title{
Role of Receptor Cycling in the Regulation of Angiotensin II Surface Receptor Number and Angiotensin II Uptake in Rat Vascular Smooth Muscle Cells
}

Michael E. Ullian and Stuart L. Linas

Department of Medicine, University of Colorado Health Sciences Center, Denver, Colorado 80262

\begin{abstract}
In vivo data on the factors controlling angiotensin II (AII) cell surface binding are conflicting. We studied the specific effects of AII on AII binding in rat mesenteric artery vascular smooth muscle cells in culture. Incubation with unlabeled AII at $21^{\circ} \mathrm{C}$ resulted in time- and concentration-dependent decreases in AII surface binding at $4^{\circ} \mathrm{C}$, with a $30 \%$ reduction after exposure to $300 \mathrm{nM}$ AII for $15 \mathrm{~min}$. Reductions in cell surface binding were due to decrements in receptor number rather than changes in binding affinity. Loss of surface receptors was mediated by receptor internalization as maneuvers that blocked ligand internalization (cold temperature and phenylarsine oxide [PAO]) attenuated AII-induced loss of surface receptors. After removal of AII, recovery of surface binding was rapid $\left(t_{1 / 2}=15\right.$ $\mathrm{min}$ ) and was mediated by reinsertion of a preexisting pool of receptors into the surface membrane rather than by new receptor synthesis. To determine the role of receptor cycling on AII-induced surface receptor loss, cells were incubated with the endosomal inhibitor chloroquine during exposure to AII at $21^{\circ} \mathrm{C}$. Incubation with AII plus chloroquine resulted in a $\mathbf{7 0 \%}$ greater loss of surface binding than after incubation with AII alone. To determine the role of receptor cycling on uptake of ligand, cells were incubated with PAO or endosomal inhibitors during exposure to AII at 4 and $21^{\circ} \mathrm{C}$. Compared with buffer these agents did not alter AII uptake at $4^{\circ} \mathrm{C}$, but decreased uptake by $12-50 \%$ at $21^{\circ} \mathrm{C}$. These results indicate that after binding AII receptors cycle and that receptor cycling attenuates AII-induced losses of surface receptors and enhances ligand uptake by providing a continuous source of receptors to the cell surface.
\end{abstract}

\section{Introduction}

Angiotensin II (AII) ${ }^{1}$ is a potent vasoconstrictor hormone. Increased circulating concentrations of AII have been implicated in the pathogenesis of some forms of hypertension and in the support of systemic vascular resistance during intravascular volume depletion. The cellular action of AII in vascular tissue is initiated by hormone binding to cell surface receptors. This

Address correspondence to Dr. Stuart L. Linas, Denver General Hospital, Department of Nephrology, 777 Bannock St., \#4000, Denver, CO 80204.

Received for publication 20 September 1988 and in revised form 24 May 1989.

1. Abbreviations used in this paper: AII, angiotensin II.

J. Clin. Invest.

(c) The American Society for Clinical Investigation, Inc.

0021-9738/89/09/0840/07 \$2.00

Volume 84, September 1989, 840-846 hormone-receptor complex, possibly in association with a specific guanine nucleotide-binding protein $(1,2)$, activates a phospholipase in the plasma membrane (3). The subsequent hydrolysis of phosphatidyl inositol bisphosphate and phosphatidyl inositol results in the activation of inositol trisphosphate and diacylglycerol intracellular signals (4-7).

Although there is information on the postbinding cellular events mediating the action of AII, less is known about the fate of AII and its surface receptor after binding. Translocation of AII to the cell interior (internalization) has been described in the adrenal gland in vivo (8), in cultured adrenocortical cells (9), and in cultured vascular smooth muscle cells (10). Little is known about the disposition of AII receptors. In other hormone systems the fate of receptors varies after binding and ligand-receptor internalization. Once inside cells receptors may be degraded (e.g., epidermal growth factor) (11), reinserted into the cell surface (e.g., LDL) (12), or extruded from cells (e.g., transferrin during erythrocyte maturation) (13). Moreover, either receptor redistribution or net loss of total receptor protein may occur in the same cell, depending on the duration of ligand exposure (e.g., insulin) (14).

To date, most studies on the control of vascular AII surface receptors have been performed in membrane preparations of blood vessels from intact animals. The specific effects of AII on AII surface receptor availability and binding properties are difficult to ascertain from these studies because in addition to AII other systemic factors appeared to alter the expression of AII receptors. These modulating factors included potassium (15), aldosterone (16), and sex hormones (17). Moreover, receptor trafficking cannot be assessed in isolated membranes because these preparations lack intracellular organs, such as endosomes, that contribute to intracellular receptor movement.

Our aims were to determine $(a)$ the specific effect of changes in AII concentration on the cellular distribution of AII receptors in an isolated system, rat vascular smooth muscle cells in culture; and $(b)$ the cellular pathways for AII receptor translocation after exposure to AII.

\section{Methods}

Vascular smooth muscle cell isolation and maintenance. The techniques for mesentric artery vascular smooth muscle cell isolation and culture were modifications of those described by Ives et al. (18) and Gunther et al. (19), and have been previously described in detail by us (20). After isolation, cells from mesenteric arteries of male SpragueDawley rats were maintained in $25-\mathrm{cm}^{2}$ tissue culture flasks at $37^{\circ} \mathrm{C}$ in a humidified $5 \% \mathrm{CO}_{2} / 95 \%$ air incubator. Culture medium consisted of MEM with Earle's salts supplemented with $10 \%$ (vol/vol) fetal bovine serum, $100 \mathrm{U} / \mathrm{ml}$ penicillin, $100 \mu \mathrm{g} / \mathrm{ml}$ streptomycin, and nonessential amino acids. Every 7-10 d cells were passaged by harvesting with trypsin-EDTA and seeded at a ratio of 1:4. Medium was changed twice weekly. Studies were performed on cells in passages 3-7.

AII binding. Vascular smooth muscle cells were passaged with a single load of a sterile repeater pipette to a $16-\mathrm{mm} 24$-well culture 
plate. This method of cell plating reduced the variability of well protein content to $<5 \%$. Binding studies were done in contiguous triplicate wells at or near confluence 4-7 d after plating by methods originally described by. Gunther et al. (19) and Penit et al. (21). Assay buffer consisted of $50 \mathrm{mM}$ Tris- $\mathrm{HCl}$ (pH 7.4), $100 \mathrm{mM} \mathrm{NaCl}, 5 \mathrm{mM} \mathrm{MgCl}$, $0.25 \% \mathrm{BSA}$; and $0.5 \mathrm{mg} / \mathrm{ml}$ bacitracin. At the beginning of each experiment culture medium was aspirated from the wells and cells were washed twice with ice-cold saline. 50-100 fmol ${ }^{125} \mathrm{I}$-AII was added to each well with or without varying amounts of unlabeled AII (0.1-10 $\mathrm{nM}$ ). The incubation volume was $0.3 \mathrm{ml}$. Binding studies were performed at $4^{\circ} \mathrm{C}$ for 90 min unless otherwise indicated. The incubation was terminated by rapid removal of the incubation medium and addition of $1 \mathrm{ml}$ ice-cold saline. Free hormone was removed by washing the intact attached cells five times with ice-cold saline. Cells were then covered with $1 \%$ SDS, detached by scraping with a rubber policeman, and transferred to a test tube. Gamma radioactivity was then counted. Specific (receptor) binding was defined as total binding minus nonspecific binding (in the presence of $1 \mu \mathrm{M}$ unlabeled AII). Nonspecific binding was $<15 \%$ of total binding. Protein content was determined by a minor modification of the Lowry technique (22); that is, absorbancy was read at 660 rather than $750 \mathrm{~nm}$. Binding constants were determined by Scatchard analysis of binding data (23) after fitting data to a line using the least squares method (24).

Acid washing. To distinguish surface-bound radioactivity from intracellular radioactivity, ${ }^{125}$ I-AII bound to cell surface receptors was removed by the acid wash technique of Crozat et al. (9). In preliminary experiments ${ }^{125} \mathrm{I}$-AII was bound to surface sites at $4^{\circ} \mathrm{C}$. Then cells were exposed to $50 \mathrm{mM}$ glycine $/ 150 \mathrm{mM} \mathrm{NaCl}, \mathrm{pH} 3$, for $10 \mathrm{~min}$ at $4^{\circ} \mathrm{C}$. After three saline washes cell-associated radioactivity was reduced to the level of nonspecific binding. Subsequent ${ }^{125}$ I-AII binding could be restored to $100 \%$ of values obtained before acid wash.

Protein synthesis inhibition. Cells in 24-well plates were incubated in growth medium with or without cycloheximide for $30 \mathrm{~min}$ at $37^{\circ} \mathrm{C}$. Then $2 \mu \mathrm{Ci}$ of $\left[{ }^{3} \mathrm{H}\right]$ leucine was added to each well for $1 \mathrm{~h}$ at $37^{\circ} \mathrm{C}$. Uptakè was terminated with an equal volume of $20 \%$ TCA. The precipitate was washed twice with saline before precipitate-associated radioactivity was determined.

Statistics. Results were expressed as the mean \pm SEM. Comparisons were made by the paired or unpaired $t$ test. For binding studies, $n$ refers to the number of groups of control (triplicate) and experimental (triplicate) wells. For protein synthesis inhibition studies, $n$ refers to the number of pairs of control (single) and experimental (single) wells.

Materials. Materials were obtained from the following sources: trypsin-EDTA, MEM, AII (unlabeled), ammonium chloride, aldosterone, chloroquine, cycloheximide, penicillin-streptomycin, monensin, and TCA from Sigma Chemical Co. (St. Louis, MO); fetal bovine serum from Hyclone Laboratories (Logan, UT); ${ }^{125} \mathrm{I}$-AII from New England Nuclear (Boston, MA); phenylarsine oxide from Fluka Chemical (Ronkonkoma, NY); $\left[{ }^{3} \mathrm{H}\right]$ leucine from ICN K\&K Laboratories Inc. (Plainview, NY); Sprague-Dawley rats from Sasco (Omaha, NE); and arginine vasopressin (AVP) from Bachem Inc. (Torrance, CA).

\section{Results}

AII binding. AII binding by vascular smooth muscle cells was specific, time dependent, protein dependent, and saturable. Equilibrium ligand binding was achieved by $90 \mathrm{~min}$ at $4^{\circ} \mathrm{C}$. In addition, under equilibrium conditions at $4^{\circ} \mathrm{C},>95 \%$ of ligand uptake was confined to the cell surface as determined by acid washing. Scatchard transformation of the binding data revealed a single class of receptors, with receptor density of $67 \pm 7 \mathrm{fmol} / \mathrm{mg}$ cell protein and a binding affinity of $2.14 \pm 0.12$ $\mathrm{nM}$ at $4^{\circ} \mathrm{C}(n=7)$. Binding parameters were stable in cells studied from passages 3-7.

AII regulation of $A I I$ binding. Cells were exposed to unlabeled AII or buffer at $21^{\circ} \mathrm{C}$. After acid wash to eliminate ligand occupancy, AII binding was performed at $4^{\circ} \mathrm{C}$. Fig. 1 shows

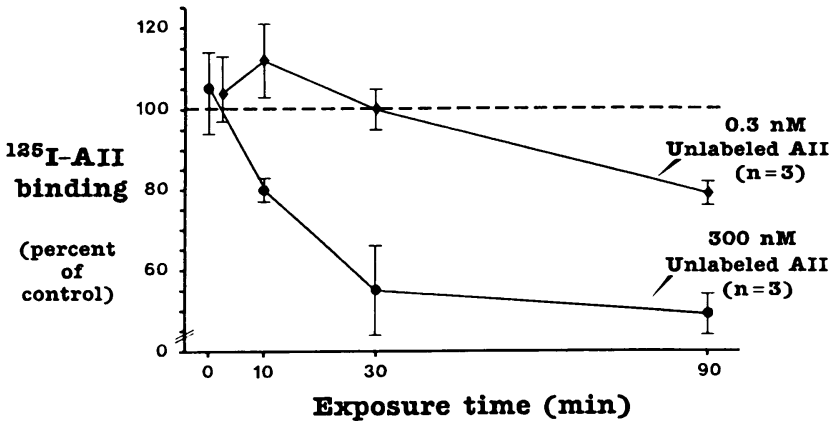

Figure 1. Time-dependent regulation of ${ }^{125}$ I-AII binding by unlabeled AII. After aspiration of the growth medium from the wells and two washes with saline at $21^{\circ} \mathrm{C}$, cells were incubated with buffer or unlabeled AII for the times indicated at $21^{\circ} \mathrm{C}$. Cells were then washed three times with ice-cold saline, and glycine-saline buffer $(\mathrm{pH}$ 3.0) was added to the cells for $10 \mathrm{~min}$ at $4^{\circ} \mathrm{C}$. After three washes with ice-cold saline, ${ }^{125} \mathrm{I}$-AII was added to the cells at $4^{\circ} \mathrm{C}$ for $90 \mathrm{~min}$. Unbound tracer was removed by five washes with ice-cold saline. Cells were then scraped from the wells and cell-associated radioactivity counted. In all experiments (unless otherwise indicated) buffer and unlabeled AII were added to cells on the same plate. Data are expressed as ${ }^{125}$ I-AII binding after exposure to unlabeled AII compared with ${ }^{125} \mathrm{I}$-AII binding after exposure to buffer.

the time course of the loss of cell surface binding. Exposure to $0.3 \mathrm{nM}$ unlabeled AII resulted in a gradual decrease in AII binding, with a $20 \%$ reduction after $90 \mathrm{~min}$. After exposure to higher unlabeled AII concentrations ( $300 \mathrm{nM})$ there was also a time-dependent decrease in binding with a $50 \%$ reduction after $90 \mathrm{~min}$.

Fig. 2 shows the effect of increasing concentrations of unlabeled AII on the loss of surface binding. There was a concentration-dependent decrease in surface binding with a threshold at $6 \mathrm{nM}$ unlabeled AII and a decrease of $30 \%$ at 300 nM unlabeled AII. Fig. 3 displays kinetic parameters derived from Scatchard transformation of AII binding curves at $4^{\circ} \mathrm{C}$ after exposure to $60 \mathrm{nM}$ unlabeled AII or buffer at $21^{\circ} \mathrm{C}$. Decreases in cell surface binding after exposure to unlabeled AII resulted from decreases in receptor density, whereas binding affinity remained unchanged.

Fig. 2 also demonstrates the specificity of AII receptor regulation. Specific binding sites for AVP (21) and aldosterone

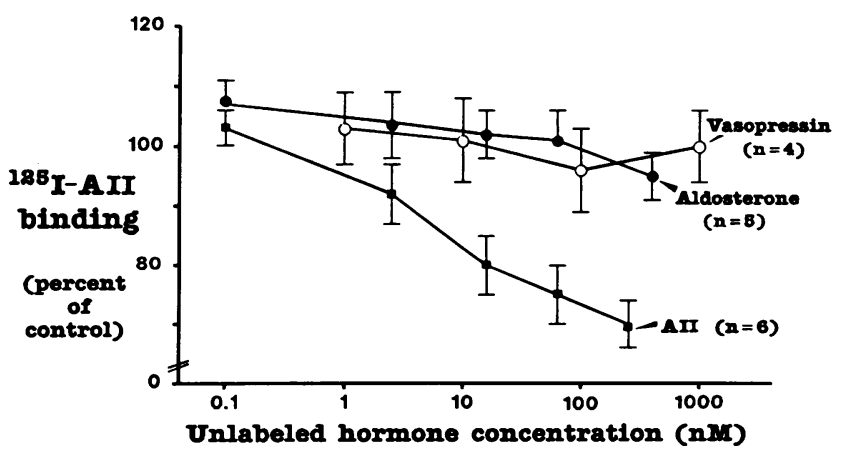

Figure 2. Dose-dependent regulation by unlabeled AII and other unlabeled hormones of ${ }^{125} \mathrm{I}$-AII binding. Cells were treated and data expressed as described in the legend of Fig. 1, except that the concentration of unlabeled hormone was varied. Exposure time was constant at $15 \mathrm{~min}$. 

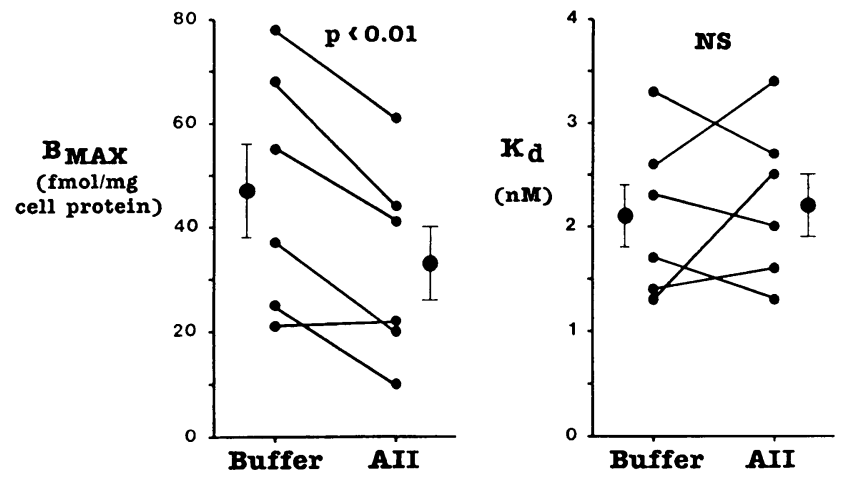

Figure 3. Changes in receptor density $\left(B_{\max }\right)$ and binding affinity $\left(K_{\mathrm{d}}\right)$ after exposure to unlabeled AII. Cells were exposed to buffer or 67 $\mathrm{nM}$ unlabeled AII for $30 \mathrm{~min}$ at $21^{\circ} \mathrm{C}$. After acid wash tracer doses (50-100 fmol) of ${ }^{125} \mathrm{I}$-AII in increasing concentrations of unlabeled AII $(0,1,200,2,400,3,600,4,800,6,400$, and 300,000 pmol $)$ were added to the cells at $4^{\circ} \mathrm{C}$ for 90 min to generate binding curves. Cells were washed free of unbound AII and the radioactivity was counted. Values for $B_{\max }$ and $K_{\mathrm{d}}$ were derived from Scatchard plots. Binding curves after exposure to buffer and unlabeled AII were generated on separate plates, and the data were corrected for protein. Data were analyzed by paired $t$ test.

(25) on/in vascular smooth muscle cells in culture have been reported. In contrast to exposure to AII, 15-min exposure to AVP or aldosterone at $21^{\circ} \mathrm{C}$ did not alter cell surface ${ }^{125} \mathrm{I}$-AII binding. To confirm that AVP receptors were functional we measured inositol phosphate responses after exposure to this ligand. As has been reported by others $(26,27)$, AVP (1-100 $\mathrm{nM}, 30 \mathrm{~s}, 21^{\circ} \mathrm{C}$ ) stimulated concentration-dependent increases in inositol bisphosphate and inositol trisphosphate (unpublished observations). Because cellular responses to aldosterone may require protein synthesis, we exposed cells to aldosterone for $3 \mathrm{~h}$ in growth medium at $37^{\circ} \mathrm{C} .{ }^{125} \mathrm{I}$-AII binding was not altered by a more prolonged exposure of cells to aldosterone. When compared with cells not exposed to aldosterone ${ }^{125} \mathrm{I}$-AII binding was $99 \pm 6 \%$ after $1 \mathrm{nM}$ aldosterone, $102 \pm 4 \%$ after 10 $\mathrm{nM}$ aldosterone, and $98 \pm 9 \%$ after $100 \mathrm{nM}$ aldosterone $(n=5$ with each concentration of aldosterone).

It has been suggested that rapid decreases in surface binding induced by exposure to ligands is a function of Tris buffer and does not occur in other buffers or in medium (28). To determine if losses of cell surface binding after exposure to unlabeled AII were dependent on Tris buffer, cells were exposed to unlabeled AII in PBS. The loss of cell surface binding occurred in PBS as well as Tris buffer. After exposure to 300 $\mathrm{nM}$ unlabeled AII for $15 \mathrm{~min}$ at $21^{\circ} \mathrm{C},{ }^{125} \mathrm{I}$-AII binding was decreased by $39 \pm 4 \%$ in PBS $(n=4)$ compared with $30 \pm 4 \%$ in Tris buffer $(n=6)$.

Mechanism of loss of cell surface receptors. We next examined the role of internalization on the loss of AII surface receptors after exposure to unlabeled AII. Fig. 4 shows the time course of ${ }^{125} \mathrm{I}$-AII internalization at $21^{\circ} \mathrm{C}: 65 \%$ of ligand was internalized by $20 \mathrm{~min}$, with a $t_{1 / 2}$ of $6 \mathrm{~min}$. Internalization was inhibitable by cold temperature $\left(4^{\circ} \mathrm{C}\right)$ or by the covalent sulfhydryl modifying agent, phenylarsine oxide. For example, after 60 min internalization at $4^{\circ} \mathrm{C}$, acid-resistant radioactivity was reduced by $84 \pm 1 \%(n=4)$ compared with internalization period at $21^{\circ} \mathrm{C}$. Internalization $\left(60 \mathrm{~min}\right.$ at $\left.21^{\circ} \mathrm{C}\right)$ of ${ }^{125} \mathrm{I}$-AII

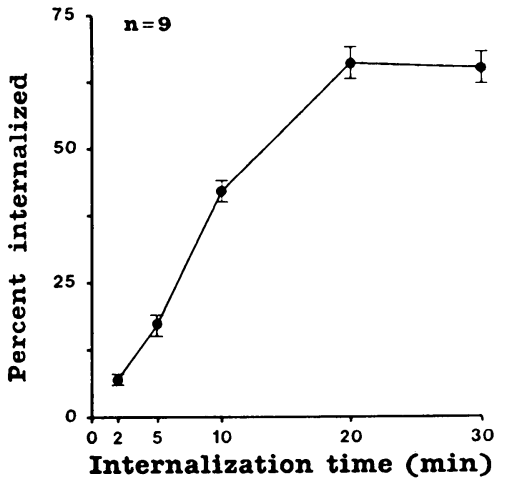

Figure 4. Time course of ${ }^{125}$ I-AII internalization. Cells were incubated with ${ }^{125}$ I-AII at $4^{\circ} \mathrm{C}$ for $90 \mathrm{~min}$. After unbound tracer was removed with five saline washes cells were incubated in buffer at $21^{\circ} \mathrm{C}$. Cell-associated radioactivity was measured after acid wash in some cells and without acid wash in others. Data are expressed as percent in-

ternalized (counts after acid wash [internalized] compared with counts without acid wash [internalized and surface bound]).

was inhibited by $83 \pm 1 \%(n=4)$ in cells preincubated with 100 $\mu \mathrm{M}$ phenylarsine oxide compared with cells preincubated with buffer alone.

To determine the effect of maneuvers that blocked ligand internalization on the loss of cell surface ${ }^{125}$ I-AII binding after exposure to unlabeled AII, cells were incubated with unlabeled AII at 4 or $21^{\circ} \mathrm{C}$ after preincubation with phenylarsine oxide. Incubation with $300 \mathrm{nM}$ unlabeled AII for 15 min resulted in a $30-35 \%$ loss of cell surface binding at $21^{\circ} \mathrm{C}$ but only a $10 \%$ loss when cells were exposed to unlabeled AII at $4^{\circ} \mathrm{C}$ for as long as 120 min (Fig. $5 \mathrm{~A}$ ). Similarly, preincubation with phenylarsine oxide attenuated unlabeled AII-induced loss of surface ${ }^{125}$ I-AII binding (Fig. $5 \mathrm{~B}$ ). These results suggest that receptor internalization occurred rapidly and that receptor internalization mediated AII-induced surface receptor loss, as maneuvers that prevented ligand internalization attenuated the loss of surface receptors after exposure to unlabeled AII.

We next studied recovery of ${ }^{125}$ I-AII surface binding after withdrawal of ligand. Cells were exposed to unlabeled AII in

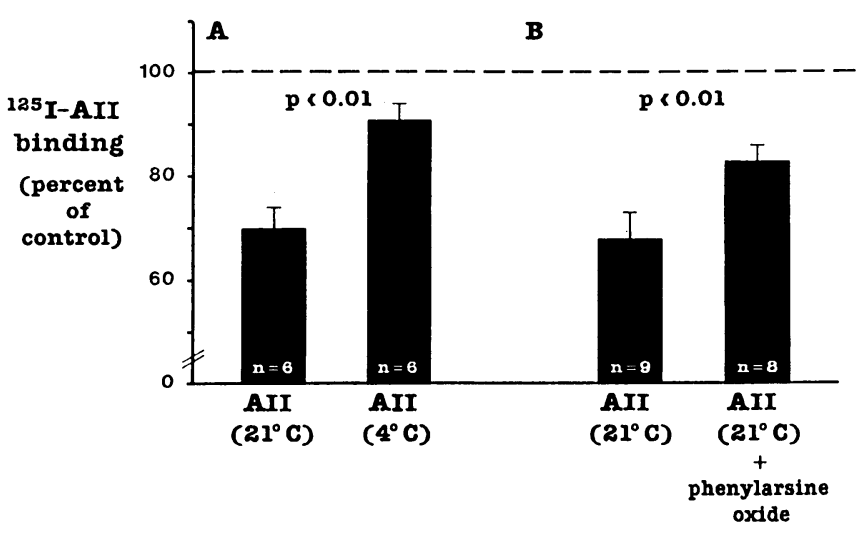

Figure 5. The effect of cold temperature $(A)$ or phenylarsine oxide $(B)$ on AII-induced loss of cell surface binding. Cells were preincubated with buffer or $100 \mu \mathrm{M}$ phenylarsine oxide for $30 \mathrm{~min}$ at $21^{\circ} \mathrm{C}$. After three saline washes cells were exposed to $300 \mathrm{nM}$ unlabeled AIl or buffer at $21^{\circ} \mathrm{C}$ for $30 \mathrm{~min}$ or at $4^{\circ} \mathrm{C}$ for $120 \mathrm{~min}$, followed by acid washing and ${ }^{125} \mathrm{I}$-AII binding as described in Fig. 1. Data are expressed as binding after exposure to unlabeled AII (with or without phenylarsine oxide preincubation) compared with binding after exposure to buffer. In each panel statistical comparisons were made by unpaired $t$ test between bars. 
concentrations ( $300 \mathrm{nM}$ ) sufficient to cause a $30 \%$ loss in cell surface binding. Fig. $6 \mathrm{~A}$ shows that recovery was rapid, with a $t_{1 / 2}$ of $\sim 15 \mathrm{~min}$ at $21^{\circ} \mathrm{C}$. The rapidity of recovery suggested that recovery occurred by translocation of existing receptors from the cell interior to the cell surface, rather than by the more time-consuming process of new receptor synthesis.

To further examine the role of reinsertion of existing receptors during recovery of surface binding, we determined the effect of protein synthesis inhibitors and agents that impair endosomal function on recovery of cell surface ${ }^{125}$ I-AII binding. In preliminary studies we determined that protein synthesis was inhibited by cycloheximide. Cells were incubated with or without cycloheximide $(25 \mu \mathrm{g} / \mathrm{ml})$ for $30 \mathrm{~min}$ at $37^{\circ} \mathrm{C}$. Cycloheximide blocked $\left[{ }^{3} \mathrm{H}\right]$ leucine incorporation into TCA-precipitable protein by $50 \pm 6 \%(n=8)$. Fig. $6 B$ demonstrates that cycloheximide had no effect on the recovery of surface binding.

To determine whether recovery of surface binding required passage through an endosomal compartment, we used agents that purportedly increase endosomal pH: chloroquine, a diffusible weak base; and monensin, a carboxylic ionophore (29). Exposure to either chloroquine or monensin blunted recovery of surface binding (Fig. $6 \mathrm{~B})(P<0.05$ for each). These results suggest that receptor trafficking through endosomes is required for recovery after AII-induced loss of cell surface receptors.

Effect of receptor reinsertion on AII-induced loss of surface binding. Because the recovery of surface binding after removal of unlabeled AII appeared to be mediated by reinsertion of existing receptors, and because the time course of receptor internalization and recovery was rapid, we questioned whether concomitant receptor reinsertion could attenuate AII-induced loss of surface binding. Cells were exposed to $0.2 \mathrm{mM}$ chloroquine or buffer alone at $21^{\circ} \mathrm{C}$ for $60 \mathrm{~min}$. After three saline washes both groups of cells were exposed to $300 \mathrm{nM}$ unlabeled AII at $21^{\circ} \mathrm{C}$ for $30 \mathrm{~min}$. Acid washing and ${ }^{125} \mathrm{I}$-AII binding at $4^{\circ} \mathrm{C}$ were performed as described in the legend of Fig. 1 . Preincubation with chloroquine accentuated reductions in cell surface binding induced by unlabeled AII by $73 \pm 4 \%(n=5)$. These results suggest that translocation of receptors through endosomes back to the cell surface partially offsets surface receptor loss during exposure to unlabeled AII.

Effect of receptor cycling on AII uptake. To further explore the consequences of rapid receptor cycling we examined the role of receptor cycling on ligand uptake. Cells were exposed to AII (tracer and unlabeled) at 4 or $21^{\circ} \mathrm{C}$ until steady-state uptake was reached $\left(30 \mathrm{~min}\right.$ at $21^{\circ} \mathrm{C}$ and $90 \mathrm{~min}$ at $\left.4^{\circ} \mathrm{C}\right)$. Steady-state uptake of AII was increased twofold at $21^{\circ} \mathrm{C}$ compared with $4^{\circ} \mathrm{C}$ (Fig. 7). To determine whether the increased uptake at $21^{\circ} \mathrm{C}$ was mediated by receptor cycling and continued uptake of ligand, uptake of tracer was examined in cells preincubated with agents that blocked internalization (phenylarsine oxide) or reinsertion (weak bases or monensin). ${ }^{125} \mathrm{I}$-AII uptake at $21^{\circ} \mathrm{C}$ was decreased after preincubation with each agent compared with preincubation with buffer (Fig. $8 \mathrm{~A}$ ). In contrast, ${ }^{125} \mathrm{I}$-AII uptake at $4{ }^{\circ} \mathrm{C}$ was not reduced by any of these inhibitors (Fig. $8 \mathrm{~B}$ ). These data demonstrate that none of the inhibitors decrease ligand binding and that receptor cycling accounts for increased ligand uptake at $21^{\circ} \mathrm{C}$.

\section{Discussion}

The results of the present study demonstrate that after AII binding to vascular smooth muscle cells, ligand and receptors are internalized. After internalization receptors appear to move through an endosomal compartment and are reinserted into the cell surface. Receptor internalization mediates AII-induced reduction of cell surface binding. Reinsertion of receptors from the cell interior completely restores surface binding after AII is removed and partially offsets losses of surface binding in the presence of AII. Finally, receptor cycling (internalization and reinsertion) enhances ligand uptake by vascular smooth muscle cells and accounts for increases in steady-state uptake at $21^{\circ} \mathrm{C}$ compared with $4^{\circ} \mathrm{C}$.

The specific effects of AII on the control of AII surface receptors and receptor trafficking are difficult to study in vivo. In addition to AII a number of other factors have been reported to alter AII surface binding. For example, potassium depletion (30) and mineralocorticoid excess (16) have been associated with increases in AII surface receptor number in smooth muscle cell membranes, while estrogens cause increases in receptor number in adrenal membranes (17). Moreover, increases in AII concentration have been reported to both increase (31) and decrease (32) receptor density and decrease binding affinity (33) in smooth muscle cell membranes. In cultured vascular smooth muscle cells we found that AII caused buffer-independent and time-, temperature-, and con-
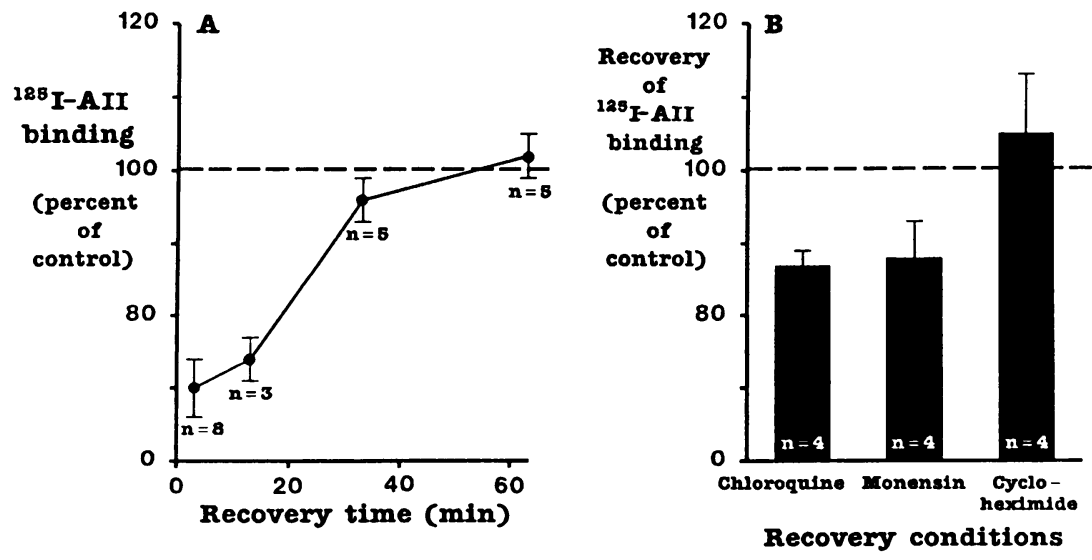
$4^{\circ} \mathrm{C}$ for $90 \mathrm{~min}$. Data are expressed as ${ }^{125} \mathrm{I}$-AII binding after recovery with inhibitor compared with ${ }^{125}$ I-AII binding after recovery with buffer. Comparisons were made by unpaired $t$ test.

Figure 6. Time course and inhibition of recovery from AII-induced loss of ${ }^{125} \mathrm{I}$-AII binding. (A) Cells were incubated with buffer or $300 \mathrm{nM}$ unlabeled AII at $21^{\circ} \mathrm{C}$ for $30 \mathrm{~min}$ and then acid washed. Some cells were bound with ${ }^{125}$ I-AII ( 0 min recovery period). Other cells were incubated in buffer at $21^{\circ} \mathrm{C}$ for the times indicated (recovery period) and then bound with ${ }^{125}$ I-AII. Data are expressed as ${ }^{125}$ I-AII binding after exposure to unlabeled AII (with recovery periods) compared with ${ }^{125} \mathrm{I}$-AII binding after exposure to buffer. (B) Cells were incubated with $300 \mathrm{nM}$ unlabeled AII at $21^{\circ} \mathrm{C}$ for $30 \mathrm{~min}$, acid washed, and exposed to chloroquine $(0.2 \mathrm{mM})$, cycloheximide $(25 \mu \mathrm{g} / \mathrm{ml})$, monensin $(10 \mu \mathrm{M})$, or buffer for $1 \mathrm{~h}$ at $4^{\circ} \mathrm{C}$ and then for $1 \mathrm{~h}$ at $21^{\circ} \mathrm{C}$ (recovery). ${ }^{125}$ I-AII binding was performed at 


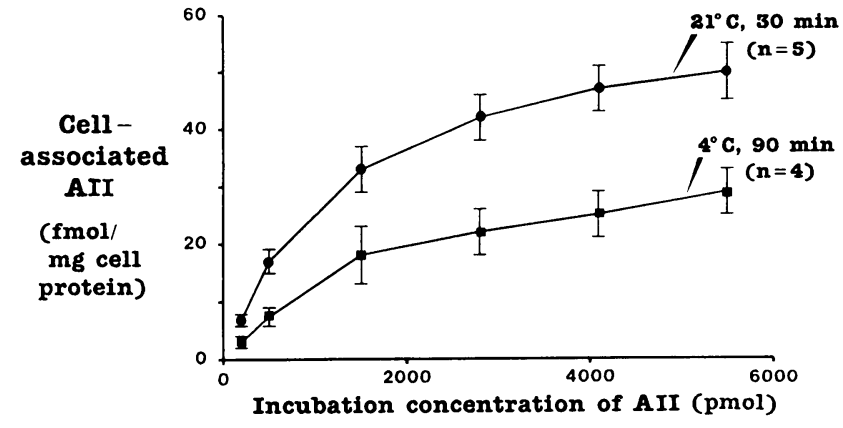

Figure 7. Uptake of AII by vascular smooth muscle cells as a function of temperature at steady-state conditions. Cells were exposed to AII (tracer and unlabeled as described in Fig. 3) at 21 or $4^{\circ} \mathrm{C}$ for the times indicated. Free AII was removed with five ice-cold saline washes and cell-associated radioactivity was determined. Studies at each temperature were performed on different plates and corrected for protein.

centration-dependent reductions in cell surface receptor number, which were reversible upon removal of AII from the culture system. This effect was AII specific, since exposure to aldosterone or AVP did not result in hormone-induced loss of AII surface receptors. Moreover, decreases in AII binding were not mediated by receptor occupancy with AII, as binding studies were performed after an acid wash procedure that removed ligand from surface receptors.

Few studies have focused on the fate of AII and its cell surface receptor after binding. Internalization of AII after binding has been demonstrated in a number of systems. Bianchi et al. injected ${ }^{125} \mathrm{I}-\mathrm{AII}$ into rats and found ${ }^{125} \mathrm{I}$-AII uptake into adrenal cells in $<20 \mathrm{~min}(8)$. Crozat et al. reported that ${ }^{125} \mathrm{I}$-AII was internalized by cultured adrenocortical cells with a $t_{1 / 2}$ of $10 \mathrm{~min}$ at $37^{\circ} \mathrm{C}(9)$. Griendling et al. reported that cultured vascular smooth muscle cells internalized ${ }^{125} \mathrm{I}$-AII with a $t_{1 / 2}$ of $3 \mathrm{~min}$ at $37^{\circ} \mathrm{C}(10)$. We also found rapid internalization of ${ }^{125} \mathrm{I}$-AII. Cells exposed to ${ }^{125} \mathrm{I}$-AII accumulated acid resistant radioactivity with a $t_{1 / 2}$ of $6 \mathrm{~min}$ at $21^{\circ} \mathrm{C}$. Moreover, maneuvers reported to reduce internalization in other systems (cold temperature and phenylarsine oxide) impaired the appearance of acid-resistant ${ }^{125} \mathrm{I}$.

Less is known about the fate of AII receptors after surface binding. Our studies suggest that AII receptors are internalized, and that losses of surface receptors are rapidly offset by receptors cycled from intracellular pools to the cell surface. Exposure to graded concentrations of ligand resulted in concentration-dependent losses of cell surface binding. AII-induced loss of surface receptors required receptor internalization because conditions shown to prevent ligand internalization $\left(4^{\circ} \mathrm{C}\right.$ or phenylarsine oxide) impaired AII-induced loss of surface binding. After removal of unlabeled AII surface binding was restored rapidly, with a $t_{1 / 2}$ of $\sim 15 \mathrm{~min}$. Reinsertion of receptors into the surface membrane apparently did not require synthesis of new receptors as recovery was rapid and occurred in the presence of the protein synthesis inhibitor cycloheximide. In many hormone systems internalization and reinsertion of receptors are linked by an endosomal pathway. Within these intracellular vesicles decreases in $\mathrm{pH}$ cause separation of ligand from receptor (34), and receptors are cycled back to the cell surface. Our results suggest a role for endosomes in maintaining AII surface receptor number in vascular smooth muscle cells as recovery of surface binding was impaired by chloroquine and monensin, agents that increase endosomal $\mathrm{pH}$ and prevent dissociation of ligand from receptor $(29,35)$. However, since these agents have additional cellular effects (for example, an increase in cytosolic $\mathrm{pH}$ by chloroquine and a decrease in cytosolic potassium concentration by monensin), it is possible that nonendosomal cellular compartments were involved in AII receptor cycling. From our work it is not possible to determine whether internalized receptors themselves or preexisting intracellular receptors were inserted into the cell surface.

In addition to the role of reinsertion in restoring surface binding after removal of unlabeled AII, our data suggest the importance of reinsertion during exposure to unlabeled AII. In this regard, reinsertion of intracellular receptors into the cell surface partially offset reductions in surface receptor number induced by exposure to unlabeled AII. When reinsertion was impaired with chloroquine so that receptors were trapped within cells, AII-induced loss of surface binding was potentiated.

Recovery from ligand-induced loss of surface receptors has been described in other hormone systems, such as beta adrenergic receptors in glioma cells (36), vasopressin receptors in hepatocytes (37), and insulin in fibroblasts (14). However, rapid receptor recovery is not a uniform finding. For example, receptors for epidermal growth factor are internalized but not returned to the cell surface (11). Also, prolonged ( $>4 \mathrm{~h}$ ) exposure to insulin results in receptor degradation and a net loss of total cell receptors (38).

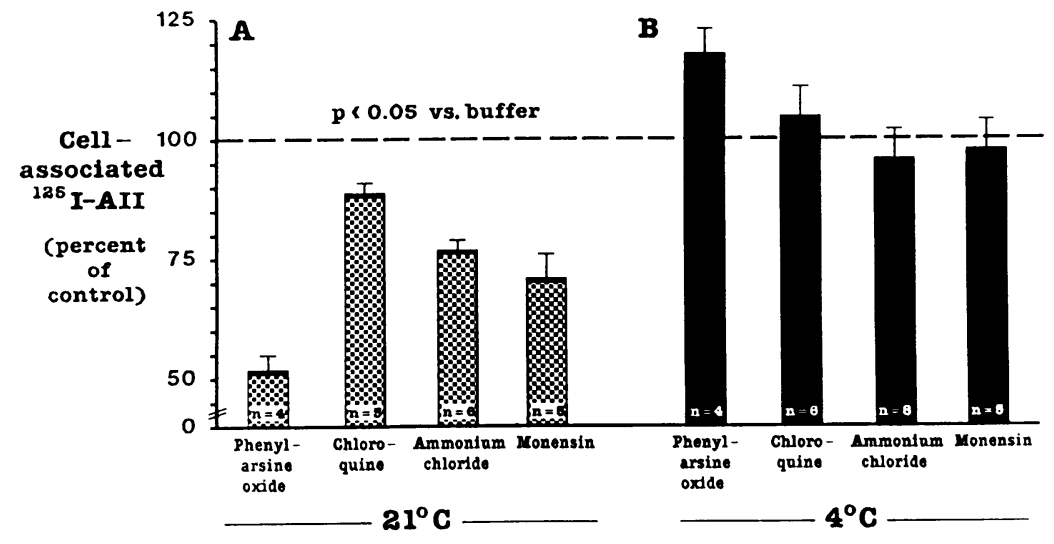

Figure 8. Effect of phenylarsine oxide and endosomal inhibitors on ${ }^{125}$ I-AII uptake at $21(A)$ and $4^{\circ} \mathrm{C}(B)$. Cells were preincubated with buffer or $100 \mu \mathrm{M}$ phenylarsine oxide for $30 \mathrm{~min}$ at $21^{\circ} \mathrm{C}$, or $0.2 \mathrm{mM}$ chloroquine, $30 \mathrm{mM}$ ammonium chloride, or $10 \mu \mathrm{M}$ monensin for $1 \mathrm{~h}$ at $4^{\circ} \mathrm{C}$ and $1 \mathrm{~h}$ at $21^{\circ} \mathrm{C}$. After three saline washes $50-100 \mathrm{fmol}{ }^{125} \mathrm{I}$-AII was added to cells for $90 \mathrm{~min}$ at $4^{\circ} \mathrm{C}$, or for $30 \mathrm{~min}$ at $21^{\circ} \mathrm{C}$. After five washes with ice-cold saline to remove unbound tracer, cell-associated radioactivity was counted. Data are expressed as counts after preincubation with inhibitor compared with counts after preincubation with buffer. Comparison was by one-tailed unpaired $t$ test. In $A$ the $P$ value refers to the comparison between each inhibitor and buffer. 
Few studies have addressed the role of receptor cycling (internalization and reinsertion) on ligand uptake. We found that steady-state AII uptake was greater at $21^{\circ} \mathrm{C}$, a temperature at which surface binding and cycling occur, than at $4^{\circ} \mathrm{C}$, a temperature at which surface binding alone occurs. Since agents that impaired internalization or reinsertion of receptors markedly reduced ligand uptake at $21^{\circ} \mathrm{C}$, the increased ligand uptake at $21^{\circ} \mathrm{C}$ was mediated by receptor trafficking. Since these agents did not affect uptake at $4^{\circ} \mathrm{C}$, they did not affect surface binding.

The results of these studies may be important in interpreting binding data performed at different temperatures in intact cells $(39,40)$. Steady-state uptake at $4^{\circ} \mathrm{C}$ represents true equilibrium surface binding (i.e., equal rates of ligand binding and ligand detachment from the receptor). In contrast, steady-state uptake at higher temperatures represents a pseudoequilibrium, presumably consisting of a complex interplay of surface binding, surface detachment, internalization, and reinsertion, as well as subsequent cycles of binding, internalization, and reinsertion. Under these conditions a steady state exists when the rate of association of radioactivity with cells equals the rate of extrusion of radioactivity from cells. Thus, binding analysis of studies performed at temperatures at which cycling occurs (e.g., $21^{\circ} \mathrm{C}$ ) overestimates the apparent number of surface receptors. In contrast, binding studies at $4^{\circ} \mathrm{C}$ yield accurate estimates of surface receptor kinetics. For these reasons we did not calculate kinetic parameters of receptor binding from steadystate uptake studies performed at $21^{\circ} \mathrm{C}$.

Of interest was the observation that ${ }^{125}$ I-AII uptake was impaired to a greater extent by phenylarsine oxide than by the endosomal inhibitors. There are at least two possible explanations for these findings. Phenylarsine oxide prevents internalization, while endosomal inhibitors leave internalization intact. Thus, the cellular entry of ligand (radioactivity) occurs in the presence of endosomal inhibitors but not phenylarsine oxide. Also, since endosomal inhibitors are lysomorphic and thus impair ligand degradation in many systems (41), these agents may impair the cellular extrusion of radioactive ligand breakdown products.

Taken together, our studies suggest that receptor cycling could contribute to the control of AII action in vascular smooth muscle cells. By providing a continuous source of receptors to the cell surface, cycling enhances AII uptake, internalization, and possibly second messenger formation. Along these lines, Griendling et al. have shown that sustained AIImediated diacylglycerol formation in vascular smooth muscle cells requires ligand-receptor internalization (10). It is possible that cycled receptors may bind additional ligand, thereby providing additional ligand-receptor complexes for internalization and diacylglycerol formation. In addition, enhancing ligand uptake cycling would result in an efficient mechanism for AII degradation. Finally, by limiting AII-induced losses of surface receptor density during exposure to AII, receptor cycling could offset AII-induced densensitization.

\section{Acknowledgments}

We thank Vicky Maltezos for preparation of the manuscript and Rochelle Marzec-Calvert for technical assistance.

This work was supported by National Institutes of Health grants HL-37694, DK-08064, and DK-07135, and by the National Kidney Foundation of Colorado.

\section{References}

1. Pfeilschiffer, J., and C. Bauer. 1986. Pertussis toxin abolishes angiotensin II-induced phosphoinositide hydrolysis and prostaglandin synthesis in rat renal mesangial cells. Biochem. J. 236:289-294.

2. Bruns, C., and D. Marme. 1987. Pertussis toxin inhibits the angiotensin II and serotonin-induced rise of free cytoplasmic calcium in cultured smooth muscle cells from rat aorta. FEBS (Fed. Eur. Biochem. Soc.) Lett. 212:40-44.

3. Berridge, M. J. 1984. Inositol trisphosphate and diacylglycerol as second messengers. Biochem. J. 220:345-360.

4. Creba, J. A., C. P. Dounes, P. T. Hawkins, G. Brewster, R. H. Michell, and C. J. Kirk. 1983. Rapid breakdown of phosphatidylinositol 4-phosphate and phosphatidyl-inositol 4,5-bisphosphate in rat hepatocytes stimulated by vasopressin and other $\mathrm{Ca}^{2+}$-mobilizing hormones. Biochem. J. 212:733-747.

5. Smith, J. B., L. Smith, E. R. Brown, D. Barnes, M. A. Sabir, J. S. Davis, and R. V. Farese. 1984. Angiotensin II rapidly increases phosphatidate-phosphoinositide synthesis and phosphoinositide hydrolysis and mobilizes intracellular calcium in cultured arterial muscle cells. Proc. Natl. Acad. Sci. USA. 81:7812-7816.

6. Kojima, I., K. Kojima, D. Kreutter, and H. Rasmussen. 1984. The temporal integration of the aldosterone secretory response to angiotensin occurs via two intracellular pathways. J. Biol. Chem. 259:14448-14457.

7. Ochi, S., Y. Fujikara, Y. Orita, Y. Tanaka, S. Shin, T. Takama, A. Wada, N. Yeds, and T. Hamada. 1986. Phosphoinositide turnover enhanced by angiotensin II in isolated rat glomeruli. Biochim. Biophys. Acta. 927:100-105.

8. Bianchi, C., J. Gutkowska, A. DeLean, M. Ballek, M. B. AnandSrivastava, J. Genest, and M. Cantin. 1986. Fate of [ ${ }^{125}$ I] angiotensin II in adrenal zona glomerulosa cells. Endocrinology. 118:2605-2607.

9. Crozat, A., A. Penhoat, and J. M. Saez. 1986. Processing of angiotensin II and $\left(\mathrm{Sar}^{1}, \mathrm{Ala}^{8}\right)$ AII by cultured bovine adrenocortical cells. Endocrinology. 118:2312-2318.

10. Griendling, K. K., P. Delafontaine, S. E. Rittenhouse, M. A. Gimbrone, and R. W. Alexander. 1987. Correlation of receptor sequestration with sustained diacylglycerol accumulation in angiotensin-II stimulated cultured vascular smooth muscle cells. J. Biol. Chem. 262:14555-14562.

11. Carpenter, G., and S. Cohen. 1976. ${ }^{125}$ I-Labeled human epidermal growth factor. Binding, internalization, and degradation in human fibroblasts. J. Cell Biol. 71:159-171.

12. Brown, M. S., R. G. W. Anderson, and J. L. Goldstein. 1983. Recycling receptors: the round-trip itinerary of migrant membrane proteins. Cell. 32:663-667.

13. Pan, B. J., and R. M. Johnstone. 1983. Fate of the transferrin receptor during maturation of sheep reticulocytes in vitro: selective externalization of the receptor. Cell. 33:967-977.

14. Knutson, V. P., G. V. Ronnett, and M. D. Lane. 1983. Rapid, reversible internalization of cell surface receptors. J. Biol. Chem. 258:12139-12142.

15. Douglas, J. G. 1981. Mechanism of adrenal angiotensin II receptor changes after nephrectomy in rats. J. Clin. Invest. 67:11711176.

16. Schiffrin, E. L., F. S. Thome, and J. Genest. 1983. Vascular angiotensin II receptors in renal and DOCA-salt hypertensive rats. Hypertension (Dallas). 5(Suppl V):V16-V21.

17. Douglas, J. G. 1987. Estrogen effects on angiotensin receptors are modulated by pituitary in female rats. Am. J. Physiol. 252:E57E62.

18. Ives, H. E., G. S. Schultz, R. E. Galardy, and J. D. Jamieson. 1978. Preparation of functional smooth muscle cells from the rabbit aorta. J. Exp. Med. 148:1400-1413.

19. Gunther, S., R. W. Alexander, W. J. Atkinson, and M. A. Gimbrone. 1982. Functional angiotensin II receptors in cultured vascular smooth muscle cells. J. Cell Biol. 92:289-298.

20. Linas, S. L., R. V. Marzec-Calvert, M. E. Ullian, and R. F. 
O'Brien. 1988. Mechanism of the antihypertensive effect of $\mathrm{K}$ depletion in the spontaneously hypertensive rat. Kidney Int. 34:18-25.

21. Penit, J., M. Faure, and S. Jard. 1983. Vasopressin and angiotensin II receptors in rat aortic smooth muscle cells in culture. Am. J. Physiol. 244:E72-E78.

22. Lowry, O. H., N. J. Rosebrough, A. L. Farr, and R. J. Randall. 1951. Protein measurement with Folin phenol reagent. J. Biol. Chem. 193:265-275.

23. Scatchard, G. 1949. The attractions of proteins for small molecules and ions. Ann. NY Acad. Sci. 51:660-672.

24. Remington, R. D., and M. A. Schork. 1970. Statistics with Applications to the Biological and Health Sciences. Prentice Hall, Inc., Englewood Cliffs, NJ.

25. Scott, B. A., B. Lawrence, H. H. Nguyen, and W. J. Meyer. 1987. Aldosterone and dexamethasone binding in human arterial smooth muscle cells. J. Hypertens. 5:739-744.

26. Meyer-Lehnert, H., C. Caramelo, P. Tsai, and R. W. Schrier. 1988. Interaction of atriopeptin III and vasopressin on calcium kinetics and contraction of aortic smooth muscle cells. J. Clin. Invest. 82:1407-1414.

27. Nabika, T., P. A. Velletri, W. Lovenberg, and M. A. Beavens. 1985. Increase in cytosolic calcium and phosphoinositide metabolism induced by angiotensin II and (arg) vasopressin in vascular smooth muscle cells. J. Biol. Chem. 260:4661-4670.

28. Marshall, S., and J. M. Olefsky. 1981. Tri (hydroxymethyl) aminomethane permits the expression of insulin-induced receptor loss in isolated rat adipocytes. Biochem. Biophys. Res. Commun. 102:646653.

29. Mellman, I., R. Fuchs, and A. Helenius. 1986. Acidification of the endocytic and exocytic pathways. Annu. Rev. Biochem. 55:663700 .

30. Paller, M. S., J. G. Douglas, and S. L. Linas. 1984. Mechanism of decreased vascular reactivity to angiotensin II in conscious potassium-deficient rats. J. Clin. Invest. 73:79-86.
31. Benedetti, R. G., and S. L. Linas. 1987. Mechanism of decreased vascular response to angiotensin II in renal vascular hypertension. Kidney Int. 31:906-912.

32. Gunther, G., M. A. Gimbrone, and R. W. Alexander. 1980. Regulation by angiotensin II of its receptors in resistance blood vessels. Nature (Lond.). 287:230-232.

33. Douglas, J. G., and G. P. Brown. 1982. Effect of prolonged low dose infusion of angiotensin II and aldosterone on rat smooth muscle and adrenal angiotensin II receptors. Endocrinology. 111:988-992.

34. Harford, J., A. W. Wolkoff, G. Ashwell, and R. D. Klausner. 1983. Monensin inhibits intracellular dissociation of asiologlycoproteins from their receptors. J. Cell Biol. 96:1824-1828.

35. Marshall, S., A. Green, and J. M. Olefsky. 1981. Evidence for recycling of insulin receptors in isolated rat adipocytes. J. Biol. Chem. 256:11464-11470.

36. Hertel, C., and M. Staehelin. 1983. Reappearance of betaadrenergic receptors after isoproterenol treatment in intact C6-cells. $J$. Cell Biol. 97:1538-1593.

37. Fishman, J. B., B. F. Dickey, N. L. R. Bucher, and R. E. Fine. 1985. Internalization, recycling, and redistribution of vasopressin receptors in rat hepatocytes. J. Biol. Chem. 260:12641-12646.

38. Marshall, S., W. T. Garvey, and M. Geller. 1984. Primary culture of isolated adipocytes: a new model to study insulin receptor regulation and insulin action. J. Biol. Chem. 259:6376-6384.

39. Wiley, H. S., and D. D. Cunningham. 1981. A state model for analyzing the cellular binding, internalization and degradation of polypeptide ligands. Cell. 25:433-440.

40. Limbird, L. 1986. Cell Surface Receptors: A Short Course on Therapy and Methods. Martinus Nijhoff Publishing, Boston. 51-96.

41. de Duve, C. 1983. Lysosomes revisited. Eur. J. Biochem. 137:391-397. 